Discourse and Communication for Sustainable Education, vol. 7, no. 1, pp. 139-148, 2016

\title{
In-depth Cultural Studies in Multicultural Group
}

\author{
Gunta Silina-Jasjukeviča and Ilze Briška \\ Riga Teacher Training and Educational Management Academy, Latvia
}

\begin{abstract}
There is much research and educational practices at all levels of education on how to deal with promoting acceptance and understanding between different cultures. A cultural study forms an important part of shaping intercultural understanding. The aim of the research is to analyze an innovative way of incorporating cultural studies in teacher education program from the perspective of encouraging multinational students to reveal common values within diverse manifestations of different cultures. The present article describes a qualitative study of multinational students' experiences in international project related to the learning about Nordic and Baltic cultural traditions. In the conclusion of the article, the efficiency of the structure of content and the process of in-depth cultural studies are analyzed. The discussion contains problems for further research of this topic. Keywords: in-depth studies, cultural studies, multicultural group, teacher training, celebration
\end{abstract}

Promoting the dialogues and understanding between different cultures is one of the essential goals for multicultural education nowadays. That's why content and principles of cultural studies is so actual in educational researches.

Multicultural education refers to any form of education or teaching that incorporates the histories, texts, values, beliefs, and perspectives of people from different cultural backgrounds. Geneva Gey in her analysis of multicultural education supposes that learning a culture helps students to understand themselves and others better by developing ethnic and cultural literacy, multicultural social competence, personal development, clarification of attitudes and values (Gey, 1994). These abilities and competences are crucially important for prospective teachers of $21^{\text {st }}$ century education in order to manage increasing cultural diversity of learners in changing communities (Šwitała, 2015).

However, in teacher education, the content of the study of cultural traditions emphasizes their attractive details instead of investigating the meanings. A particular culture appears in this learning as a collage of interesting and funny facts. In order to keep political correctness and avoid unexpected contradictions in communication between representatives of different cultures, all of the selected topics are unambiguous and simplified.

So, the focus of learning is oriented mostly towards identifying the differences between various cultures rather than towards identifying their common values. Another 
common problem of the realization of cultural studies amongst all mainstream models of multicultural education is recognized: they have a tendency to essentialize and thus objectify and stereotype identities (McBrien, Brandt, 1997). This relates more to the understanding of the traditional culture of particular ethnicity. By ignoring the idea, that the similarities between different cultures can be found directly in ancient traditions, a huge potential resource for obtaining mutual understanding cannot be exploited.

In this context, the aim of the recent study is to analyze the opportunities of traditional celebration as a specific learning content and situation for promoting in-depth cultural studies in multicultural group.

For this reason, the concept of in-depth cultural studies is analyzed, the holistic content of traditional celebration is substantiated and teaching strategies are selected for the realization of in-depth cultural studies in multinational group.

A qualitative study of students' experiences in an international project related to the acquisition of a Nordic and Baltic cultural tradition (the Autumn equinox celebration) is described in the article.

\section{Theoretical Background}

Cultural studies as an inter-disciplinary field of research and teaching investigates how culture creates and transforms individual experiences, identities, everyday life, social relations and power (Bennett, Grossberg, Williams, 2005; Grossberg, 2010). Gilbert B. Rodman highlights the aspect of understanding how meaning is generated, disseminated, contested, bound up with systems of power and control, and produced from the social, political and economic spheres within a particular social formation or conjuncture (Rodman, 2015).

In context of multicultural education, "culture" usually is defined in the broadest possible sense, encompassing race, ethnicity, nationality, language, religion, class, gender, sexual orientation (Farr, 2010). In the framework of the research, culture is interpreted from the perspective of symbolic anthropology (Geertz, 1973). Clifford James Geertz's understanding of culture as "an accumulated totality of symbol-systems (religion, ideology, common sense, economics, sport, etc.) in terms of which people make sense of themselves and their world, and represent themselves to themselves and to others" (Geertz, 1973, 47). Geertz's "thick description" approach has become recognized as a method of symbolic anthropology, enlisted as a working antidote to overly technocratic, mechanistic means of understanding cultures, organizations, and historical settings.

This approach deals with opposition between concepts of cognition in-depth and surface (Shusterman, 2002; Welsch, 1996). Surface deconstructs any structure, perceiving all phenomena of culture as equally significant, on one layer. In contrast, an in-depth cultural study takes for granted a holistic structure of culture: knowledge about culture does not only refer to objective, evident facts, but also includes different layers of meanings, symbols, emotional experiences and complex contexts; they are open for ambiguous interpretations (Bennett, Grossberg, Williams, 2005; Grossberg, 2010; Hanley, 1999). Therefore, the objective and critical explanations of cultural phenomena are not enough for learning the culture; but the learner's subjective sense must be involved in study process, too.

In this respect, in-depth learning fits with socio-cultural learning theory which integrates learning as individual construction of knowledge in accordance with one's 
subjective sense and experience, with social learning and communicating cultural contexts (Kron, 2004; Jonassen, 1999; Held, 2006). Another source dealing with subjective sense of learner is approach of experiential learning (Dewey, 1979; Kolb, 1984; Griffin, Holford \& Jarvis, 2003). Elements of outdoor pedagogy helps to involve students' sensor experience in learning, too (Dahlgren \& Szczepanski, 1998).

Cultural anthropologists see that holistic structure of culture unites five components: time, space, participants, ritual activity and meaning (Geertz, 1973; Toporov, 1980; Baiburin, 1993; Bykova, 2000; Lavrenova, 2010; Filatova, 2012). Example, which is familiar to representatives of all cultures of this structure is celebration - meaningful meeting of people in particular time and place, with customary activities and common intents. That is why a celebration was chosen as a form of situation for in-depth cultural studies, although the festivity usually is not associated with learning.

In traditional seasonal celebrations, structural components mentioned above are interrelated and deeply rooted in context of natural processes, social life and worldview. In Figure 1, the holistic content of traditional celebration of Autumn equinox is structured after Albert Baiburin (Baiburin, 1993).

All these components are necessary to complete an in-depth understanding of cultural tradition.

Inadequate time and space will cause a discrepancy between person's activity and actual feelings. If participants are absent in the structure, culture becomes lifeless like a theoretical construction (Rancāne, Siliņa-Jasjukeviča, Briška, 2014). Without ritual, there is no meaningful activity - no opportunity for students to be personally involved and to obtain new experiences. Without understanding the meaning of activities, all actions seem simplistic and senseless.

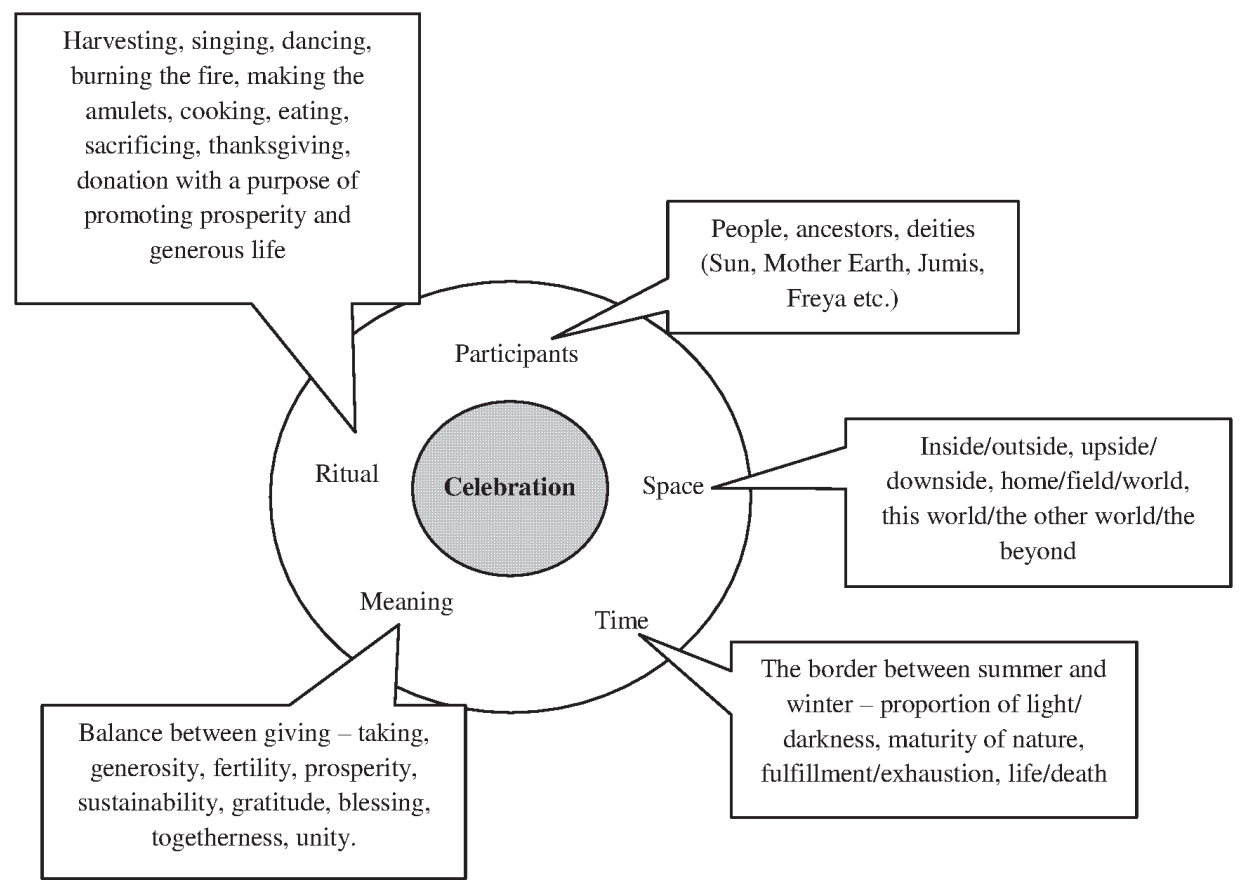

Figure 1. Structure of the content of traditional celebration 
The in-depth cultural study was realized in an intensive week's course of the Teacher Education Network. The course was a last part of a 3-years international project entitled Mythology, culture and identity in the Nordic and Baltic countries, organized by Nordic Council of Ministers'. The third year of a project was dedicated to Baltic mythology; its title was Baltic and Nordic cultural identity through traditional seasonal celebration: Autumn equinox celebration. The aim of the course was to strengthen bonds between the Nordic and the Baltic countries through in-depth cultural studies. In contrast with previous years, this intensive week was concentrated not on performance for public, but rather on investigation of cultural context - common preparation and participation in ritual in order to obtain personally meaningful holistic experience of traditions that are actual for $21^{\text {st }}$ century society.

The challenge of the project was to find a balance between in-depth learning environment based on the Latvian ethnographical tradition and an opportunity for people with different cultural backgrounds to participate fully in the creation of an event with a particular content of their cultures.

The international course was planned at the end of September. Traditionally, this is the proper time for Autumn equinox celebration, which is common to all traditional cultures in the Nordic and Baltic countries (the culmination of autumn, the end of harvesting, the remembrance of ancestors etc.). Each participating institution prepared and presented homework - research entitled "Traditions of the Autumn Equinox in my Culture". So, the common perception of time in the context of seasonal rhythms of nature was expanded in diverse examples from different cultures.

To promote an authentic space, a real socio-cultural environment - a farmhouse in the countryside - was chosen for the celebration - the main event of the intensive week's course. The components of an out-door learning provide a rich background for different ritual activities. The participants' movement from house to yard, from oak tree to hill, from fireplace to dance floor, from the boundaries to the center, in accordance with traditional ritual activities, provides variety of visual, audial, smell, tactile and kinesthetic perceptions, as well as different experiences of emotions and meanings.

The students' activities in the Autumn Equinox celebration were aimed at common preparation and participation in ritual. The traditional ritual contains elements of different activities also included in the curriculum of primary education and teacher professional education in all participant countries: music - in the form of appropriate songs, instrument playing; native language and drama - such as in storytelling, ritual behavior, organization of the event, dances and ritual games, creating the atmosphere; visual arts and crafts such as the presentation of the space used for the ritual and the attributes of the ritual itself, etc. Knowledge of the ritual activities of different cultures was acquired in the mutual learning process, which included presentations, lectures, workshops, warm-up sessions, discussions, etc. Thus common experience of the multinational group was enriched by a huge amount of various cultural expressions.

The fourth component of the holistic structure of celebration - the participants relates to active involvement of all persons in the preparation of festivity and celebration. According to traditions, each person finds his or her appropriate way of acting in the ritual. There are no spectators and actors as in performance. Learning by doing - different kinds of workshops, where each group is taking responsibility for a particular part of the celebration - provides an active participation of everyone. 
Meaning as a deep, invisible layer of traditions, was treated in different ways in this intensive course. The participants investigated the old and current autumn equinox traditional rituals or their traces in the participants' cultures. Subsequent discussions, reflections and lectures helped to capture acknowledgement of common cultural values within activities that were different in form. The resultant framework of common meanings provided a basis for the background of the Autumn equinox celebration. The acknowledgment of common cultural values (gratitude, unity, prosperity, fertility etc.) as a starting point of the course was a basis for problem-oriented learning.

\section{Research Methodology}

A qualitative study of the students' experiences was made during an intensive week's course, with the purpose of exploring how traditional celebration can promote in-depth cultural studies for multinational students. The participants' reflections in the form of survey with open questions were realized at the end of each day and in the end of course. The participants were asked to reflect the highlights of their day and of the course as a whole. As specific answers were not offered, respondents had to make conclusions by individual verbalizing their deeper experiences. It was a good opportunity for researchers to discover new ideas and unexpected points of view (Mayring, 2007; Saldana, 2012). Qualitative analysis of the data was carried out by two experts. The data were coded independently, then results of the analysis were compared, discussed and common conclusions were made.

Selection - multinational group - consisted of 34 bachelor and 4 master students and 17 teachers from teacher education institutions, elementary education, music, drama and art education programs. 8 teacher education institutions from 6 countries with different religious, political, educational and cultural traditions, economy and history Denmark, Estonia, Iceland, Latvia, Lithuania and Norway were represented by $2-4$ participants each. In additions, students and teachers belonged to a different age group. There were 5 male and 50 female participants. All teachers were involved in course preparation and organization with lectures, workshops and enrichment of an event with contribution of different countries. In celebration they were equal participants.

\section{Research Results}

In total, 175 reflections were collected. They were analyzed to look for indicators of in-depth cultural studies and perception of culture surface.

Reflections were read through, if possible, only a short phrase or a word was used in order to assign a symbolical, essence-capturing attribute of the participants' experience. Then generalization was undertaken by grouping codes with similar meaning into one category (Huber, Gürtler, 2004; Mayring, 2007; Saldana, 2012). In each category high and low level in-depth cultural studies was found.

One group of codes was formed by expressions related to the wholeness of cultural content. Codes as time (autumn and harvesting traditions), space (countryside, farmhouse, nature), rituals (traditions, dances, songs, games, fire lighting, ritual attribute making - dolls, food, crowns, lanterns etc.), meanings (thanksgiving, fertility, gratitude, honoring ancestors) and participants (we, Latvians, other, all together etc.) were mentioned 
there (Table 1, a). A statement of separate facts without context was qualified as a superficial level of obtaining the content, explanation/ interpretation and interrelations between facts and contexts. Also, an interrelation between person and society, or human and nature etc. were used to identify a holistic way of learning the content of culture, in accordance with Bennet, Grosberg etc. (Bennett, Grossberg, Williams, 2005; Grossberg, 2010; Rode, 2013; Cutanda, Murga-Menoyo, 2014). So, if a person's reflections matched all mentioned components, his level of cultural studies can be evaluated as in-depth.

The second group of codes combines the students' expressions, such as getting to know and remember facts about (culture), to create, to reveal (get insight), to share, to learn, to explore, to look for and find, to implement knowledge in practice, to understand (traditions, history, causality etc.). They represent students' learning as a reproductive or active process (Table 1, b). By analysis of the structure of codes, expressions about active learning - learning by doing, cooperative learning, discovery learning, meaningful learning, and experiential learning - are recognizable. They contrasted evidently with the expressions, where reproduction of historical information was mentioned.

The third group of codes represents attitudes towards in-depth cultural studies. Expressions such as being (together, in nature, as a part of ritual), being involved, creating, contributing, represent ones' involvement in the interaction between people and cultures (Table 1, c). Description of respondents' subjective evaluations and emotional states as fun, funny, amazing, challenge, challenging, interesting, frustration, meaningful, surprise, pride, unity, gratitude - characterize this category as well. These codes can be distinguished as being only a reaction to the event or being "inside" of event, what allows to think about obtaining deep, direct, holistic experience (Dewey, 1979; Dabrowski, 1967; Vidnere, 1997). Each person's attitude reveals to what extent he/she is a participant of an event, or whether he/she is a passive observer/ consumer. This aspect is crucial from the point of view of the ritual, because the ritual demands a high level of involvement from each participant (Baiburin, 1993).

The categories and expressions related to surface versus in-depth experiences of cultural studies were found as the result of the generalization. They are represented in Table 1.

Table 1

Respondents' Experiences of In-Depth Cultural Studies

\begin{tabular}{|c|c|c|c|c|}
\hline \multirow[b]{2}{*}{ Category } & \multicolumn{2}{|c|}{ Typical expressions } & \multirow[b]{2}{*}{ Low/ high level } & \multirow[b]{2}{*}{ Criteria } \\
\hline & $\begin{array}{c}\text { Perception of } \\
\text { surface cultural } \\
\text { studies } \\
\end{array}$ & In-depth cultural studies & & \\
\hline 1 & 2 & 3 & 4 & 5 \\
\hline a) Content & $\begin{array}{l}\text { Nice to know } \\
\text { about traditions, } \\
\text { to arrange } \\
\text { a beautiful song. }\end{array}$ & $\begin{array}{l}\text { Time spent looking for meanings } \\
\text { in life and founding them in this } \\
\text { week, understanding the reason/ } \\
\text { meaning of different rituals. } \\
\text { To choose a proper time, place } \\
\text { and situation for fire song. } \\
\text { Exploring my own identity and } \\
\text { seeing how others see the world. }\end{array}$ & $\begin{array}{l}\text { Separate facts/ } \\
\text { Interrelations } \\
\text { of facts }\end{array}$ & $\begin{array}{l}\text { Holistic } \\
\text { content }\end{array}$ \\
\hline
\end{tabular}




\begin{tabular}{|c|c|c|c|c|}
\hline \multicolumn{5}{|c|}{ Sequel to Table 1} \\
\hline 1 & 2 & 3 & 4 & 5 \\
\hline $\begin{array}{l}\text { b) Process } \\
\text { of learning }\end{array}$ & $\begin{array}{l}\text { Get to know and } \\
\text { remember new } \\
\text { facts about my/ } \\
\text { other culture, } \\
\text { unique customs. }\end{array}$ & $\begin{array}{l}\text { To share, to learn, to explore, } \\
\text { to participate, to create; all } \\
\text { knowledge was used in practice; } \\
\text { all things were useful, insightful } \\
\text { for celebration. } \\
\text { I understand the history behind } \\
\text { traditions better. }\end{array}$ & $\begin{array}{l}\text { One/ multiple } \\
\text { layers of } \\
\text { learning }\end{array}$ & $\begin{array}{l}\text { Active, } \\
\text { diverse } \\
\text { learning }\end{array}$ \\
\hline c) Attitude & $\begin{array}{l}\text { I have lot of fun, } \\
\text { Funny, that's it! }\end{array}$ & $\begin{array}{l}\text { Being (together, in nature, as a } \\
\text { part of ritual), being involved, } \\
\text { feeling (others etc.). } \\
\text { Challenging but also interesting } \\
\text { to dig deeper into, our contri- } \\
\text { bution... creating. }\end{array}$ & $\begin{array}{l}\text { Observe from } \\
\text { outside/ be } \\
\text { inside }\end{array}$ & $\begin{array}{l}\text { Perso- } \\
\text { nally } \\
\text { meaning- } \\
\text { ful }\end{array}$ \\
\hline
\end{tabular}

Several codes, which do not fit into any previous group, show a direct impact on the participant's in-depth cultural experience. For example, expressions "I reflected my own identity" and "I have an understanding of, how others see the world", "it (cultural studies) makes you a better person" relate to development and indicate a better understanding of both the studied subjects and of other people. Such expressions as " $p o p$ culture and urbanization make people shallow", "you understand the world better when you learn about their culture, habits, rituals, beliefs" show that the course participants have reflected their understanding of the processes, through which societies and the diverse groups within them come to terms with history, community life, and the challenges of the future (Rodman, 2015).

Cultural diversity was provided in the course through wide range of autumn traditions presented to others by all participating countries. Different cultural expressions - Lithuanian multipart songs - sutartines, devoted to the Sun, Denmark traditions of blessing the harvest in Christian church, multimedia art, examples of Islandic old family stories, ancient Latvian fertility rite, traditions of honoring the ancestors etc. presented in different languages reveals the diversity of participants' personal preferences and cultural understanding. In reflections we found many expressions like: "I feel unity", "Estonians and Latvians are so similar", "we are the same", "we are so different, but in the same time so similar", "we have more similarities than differences", "I think, I understand others better". It means, that implementation of the frame of Latvian traditions of Autumn equinox celebration, provided for project participants from different cultural backgrounds an opportunity to realize the common values of diverse cultures. Therefore, the main goals of multi-cultural education are reached (Gey, 1994).

If we relate these expressions to the context of the course content, we can find, that they are inspired by particular learning experiences - that in-depth cultural studies can create opportunities to learn meaningfully - to involve multiple cognitive processes not only the reproduction of mere facts.

In reflections, participants recognized, that these experiences are raised by common activities and conversations during preparation of festivity and moments of emotional culmination during the ritual: "practical learning in the right surrounding", "singing together with all people", "creating fire sculpture together", "experience of quiet contemplation and concentration on lively fest", "it is more than historical view to traditions", 
"folk music and celebration in nature", "it is so wonderful the way we all contributed with our own traditions and together make celebration".

This fact allows to conclude, that chosen experiential and socio-cultural learning strategies are effective for in-depth cultural studies.

It can be assumed, that the experimental course of Autumn equinox traditions provided a good opportunity for students of different cultures to find out the common values.

Student's reflections contained features of a high level of in-depth studies, but at the same time, there were examples of low level, too. This fact allows to conclude, that there are any other conditions affecting the student experience, but it is a topic of another study.

\section{Conclusions and Discussion}

The preparation for a traditional seasonal festivity and celebration can enable the students with different cultural backgrounds to find out common values, if the studies are in-depth:

- content of learning (cultural traditions) is structured as a unity of time, space, participants, ritual and meanings;

- cultural traditions (celebration) are realized in diverse active learning by exploring, sharing, creating, feeling, reflecting, discussing, learning from each other, using new knowledge in practice;

- learners regard their cultural studies as being personally meaningful.

The criteria and indicators of in-depth cultural studies can be suggested within three categories: the acquisition of the content of culture, the learning process, and personal involvement.

The development of the students' performance proceeded from perception of separate components of content to understanding the wholeness, from one layer of learning to multiple ones, from passive consuming to common creation, from observation to active participation.

Similarities of different cultures are not obvious/ visible and are not easily expressible in words; they are hidden in the depths of meanings, senses, feelings. If we want representatives with different historical, religious, political views and diverse experiences of contacts with other cultures, and who also have different learning motivations, and different readiness to invest or take challenges to step out of their comfort zone to discover the common values, the process of learning must create an opportunity to reveal those deep levels of culture.

The study indicates several disputable questions for in-depth cultural studies in multicultural groups:

- An in-depth cultural studies is not a conventional practice in the educational process of the teacher training because of its complexity and integrity.

- The components of in-depth cultural studies cannot be included in an ordinary curriculum, because they cannot be split clearly into the separate subjects (such as music, drama, crafts etc.).

- Another problem is within the assessment of the outcomes of learning. If the content of learning is integrated and it is realized by multiple activities, the reflection and assessment forms must be developed carefully in accordance with learning goals. 
- A wide range of learning outcomes can be reached at the same time as in-depth studies. If the dominant goals are not set and mutually agreed upon by the participants, the learning is less effective.

\section{References}

Benett, T., Grosberg, M., \& Williams, R. (2005). New keywords: a revised vocabulary of culture and society. Malden, MA: Blackwell Pub.

Brandt, R. \& McBrien, J. L. (1997). The language of learning: a guide to education terms. Alexandria, VA: Association for Supervisions \& Curriculum Development.

Cutanda, G. A; Murga-Menoyo, M. A. (2014). Analysis of mythical-metaphorical narratives as a resource of education in the principles and values of sustainability. Journal of Teacher Education of Sustainability, 16(2), 18-38.

Dabrowski, K. (1967). Personality shaping through positive disintegration. Boston: Little Brown.

Dahlgren, L. O. \& Szczepinski, A. (1998). Outdoor education. Literary education and sensory experience. Linkoping: Kinda Education Center.

Dewey, J. (1979). Art as experience. New York: A Paragon Book.

Farr, S. (2010). Teaching as leadership: the highly effective teacher's guide to closing the achievement gap. San-Francisco: Jossey-Bass.

Gay, G. (1994). A synthesis of scholarship in multicultural education. North central regional educational laboratory. Urban education program. Retrieved January 5, 2016, from https://archive.org/details/ERIC_ED378287

Geertz, C. (1973). The interpretation of cultures. New York: Basic Books.

Griffin, C., Holford, J. \& Jarvis, P. (2003). The theory \& practice of learning. London: Kogan page.

Grossberg, L. (2010). Cultural studies in the future tense. Durham, New York: Duke University Press.

Hanley, J. (1999). Beyond the tip of the iceberg. Five stages toward cultural competence. Reaching today's youth, 3(2), 9-12.

Helds, J. (2006). Mācīšanās kā konstruktīvs un sistēmisks jēdziens. [Learning as systemic and constructivistic concept]. No zināšanām uz kompetentu darbību. LU: Akadēmiskais apgāds, 31-35.

Huber G. L. \& Gürtler, L. (2004). AQUAD6. Ingeborg: Huber Verlag.

Jonassen, D. H. (1999). Designing constructivist learning environments. In C. M. Reigeluth (Ed.), Instructional design theories and models: A new paradigm of 217 instructional theory. (pp. 215-239) Volume II, Mahwah, NJ: Lawrence Erlbaum Associates.

Kolb, D. A. (1984). Experiential learning: experience as the source of learning and development. NY: Englewood Cliffs.

Kron, F. W. (2004). Grundwissen didaktik. [General Didactics] Basel, Minhen: Ernst Reinhard Verlag.

Mayring, P. (2007). On generalization in qualitatively Oriented Research. Forum Qualitative Sozialforschung [Forum: Qualitative social research], 8(3), Art. 26. Retrieved January 25, 2016, from http://www.qualitative-research.net/index.phb/fqs/article/ viewArticle/291/641 
Rancāne, A., Siliņa-Jasjukeviča, G. \& Briška, I. (2014). Saules gads. Ziemassvētki. [Solar year. Winter Solstice]. Riga: Madris.

Rode, O. (2013). Educational and psychological aspects of environmental awareness and a sense of belonging. Discourse and Communication for Sustainable Education, 4, 67-79.

Rodman, G. B. (2015). Why cultural studies? Malden, MA: Wiley Blackwell.

Saldana, J. (2012). The coding manual for qualitative researchers. 2nd Edition. London: SAGE Publications Ltd.

Shustermann, R. (2002). Surface and depth. Dialectic of criticism and culture. Ithaca, New-York: Cornell University Press.

Šwitała, E. (2015). Teachers values related to sustainable development in Polish and Latvian secondary schools. Discourse and Communication for Sustainable Education, 6, 67-79.

Welsch, W. (1996). Grenzgänge der ästhetik. [Border crossings of aesthetics] Stuttgart: Reclam.

Vidnere, M. (1997). Ar asarām tas nav pierādāms. [With tears it cannot be proved]. Rìga: LU.

Baiburin, A. K. (1993). Ритуал в традиционной культуре. Структурно семантический анализ восточно славянских обрядов. [Ritual in traditional culture. Structurally semantic analysis of the eastern Slavic rites]. Saint-Petersburg: Science Publisher.

Bykova, E. V. (2000). Традиция как способ формирования и функционирования народной культуры. Народная культура в современных условиях [Tradition as a way of formation and functioning of the ethnic culture. Traditional culture in the modern condition]. Moscow: Russian Institute of Cultural Research.

Filatova, E. А. (2012). Праздник как единство игры и культуры [Feast as an unity of game and culture]. Вестник Челябинского университета. Философия. Социология. Культурология. [Bulletin of the University of Chelyabinsk. Philosophy. Sociology. Culturology], 35(289), 108-112.

Lavrenova, O. А. (2010). Пространства и смыслы: Семантика культурного ландшафта [Spaces and meanings: The semantics of the cultural landscape]. Moscow: Institute of Heritage.

Toporov, V. N. (1980). Праздник [Celebration]. Мифы народов мира: Энциклопедия [Myths of the world: an encyclopedia]. Moscow: Science, 329-331.

Correspondence concerning this paper should be addressed to Dr. Gunta SiliņaJasjukeviča and Dr. Ilze Briška, Riga Teacher Training and Educational Management Academy, Imantas 7. līnija, Rīga, LV 1067, Latvia. Email: gunta.silinajasjukevica@rpiva.lv, ilze.briska@rpiva.lv 